\title{
Evaluation of protein: lipid ratio on growth, feed efficiency, and metabolic response in juvenile yellowtail snapper Ocyurus chrysurus (Bloch, 1791)
}

\author{
Martín Arenas $^{1}(\mathbb{D})$, Alfonso Álvarez-González ${ }^{2}$, Álvaro Barreto ${ }^{3}{ }^{\mathbb{D}}$, Adolfo Sánchez $^{4}(\mathbb{D}$ \\ Gerard Cuzon ${ }^{4}$ \& Gabriela Gaxiola ${ }^{4}$ \\ ${ }^{1}$ Posgrado de Ciencias del Mar y Limnología, Universidad Nacional Autónoma de México \\ Coyoacán, Ciudad de México, México \\ ${ }^{2}$ Laboratorio de Acuicultura Tropical, DACBIOL, Universidad Juárez Autónoma de Tabasco, México \\ ${ }^{3}$ Posgrado en Ciencias Biológico Agropecuarias, Universidad Autónoma de Nayarit, México \\ ${ }^{4}$ Unidad Multidisciplinaria de Docencia e Investigación de Sisal, Facultad de Ciencias \\ Universidad Nacional Autónoma de México, México \\ Corresponding author: Gabriela Gaxiola (mggc@ ciencias.unam.mx)
}

\begin{abstract}
This study was conducted to evaluate juveniles' Ocyurus chrysurus $(13.7 \pm 0.45 \mathrm{~g}$ initial weight) to utilize lipid as an energy source on growth, feed efficiency, body composition, digestive and hepatic enzyme activities. Four diets of two protein levels (40 and 50\%) with two lipid levels (6 and 12\%) and 2\% of digestible carbohydrates were formulated. Fish were fed for 60 days to apparent satiation at a stocking density of 10 fish per tank $(100 \mathrm{~L})$. Growth gain of fish fed $50 \%$ dietary protein was higher than of fish fed $40 \%$ dietary protein $(P<0.05)$. However, feed efficiency was significantly higher at 12 than $6 \%$ of dietary lipid. Whole-body lipid and glycogen in the liver increased dramatically with dietary lipid content-alkaline protease activity trend increased as dietary protein increased. Trypsin activity increased significantly as dietary lipid decreased, whereas chymotrypsin activity showed the opposite trend $(P<0.05)$. Bile salt-dependent lipase activity trend towards increasing as dietary energy decreased. Glucose-6-phosphate dehydrogenase (G6PDH), 6phosphogluconate dehydrogenase (6PGDH), and fructose-1, 6-biphosphatase (FBPase) significantly increased with increasing dietary lipid levels. However, alanine aminotransferase (ALT) activity increased with dietary protein content. On the other side, pyruvate kinase (PK) activity increased with both dietary protein and lipid content. This study indicates that high dietary lipid (12\%) improved the feed efficiency but did not reduce dietary protein demand in juveniles $O$. chrysurus.
\end{abstract}

Keywords: Ocyurus chrysurus; Lutjanidae; dietary lipid; protein-sparing effect; carnivorous fish

\section{INTRODUCTION}

Protein is the main component in fish feed formulation and the most expensive dietary component (OlivaTeles et al. 2020). In fish, protein is not only important for growth (protein synthesis) but also plays a central role in energy balance (ATP production) (Jia et al. 2017), since the protein supply in the diet is excessive, or the energy level from non-protein sources is insufficient (NRC 2011). Therefore, it is important to develop diets with an adequate protein: energy balance (Catacutan et al. 2001, Kim et al. 2004, Abdo de la Parra et al. 2010).

Corresponding editor: Crisantema Hernández
Lipids are the main non-protein energy source for fish and provide essential fatty acids, which play an important role in growth and health (Tocher 2003). For energy purposes, an adequate inclusion of lipid levels in the diet can help reduce the catabolism of dietary protein in fish (Shimeno et al. 1996, Lee et al. 2002, Guo et al. 2019). Conversely, excessive or deficient dietary lipid levels could adversely affect growth performance, increase factor conversion ratio (FCR), and lead to fat deposition (Peres \& Oliva-Teles 1999, Tuan \& Williams 2007). On the other hand, fish's ability to use dietary lipid as a non-protein energy source can be influenced by the content of dietary 
carbohydrates, which can also serve as sources of nonprotein energy (Shimeno et al. 1981, Zhou et al. 2016, Guerrero-Zárate et al. 2019).

Yellowtail snapper Ocyurus chrysurus (Bloch, 1791) (Pisces: Lutjanidae) is a highly valued tropical carnivorous marine fish on the east coast of America (McClellan \& Cummings 1998, Brulé et al. 2008, Cladis et al. 2014). O. chrysurus is considered a good candidate for aquaculture. This species has the advantages of spawning without the use of hormones, is tolerant of handling, and accepts artificial feed (Watanabe et al. 1998, Turano et al. 2000, GutiérrezSigeros et al. 2018). Thus, it is necessary to develop a commercial diet for this species. Previous reports revealed that $O$. chrysurus have a high dietary protein requirement $(\geq 50 \%)$ (Enríquez et al. 2017). No studies concerning $O$. chrysurus ability to utilize dietary lipids as energy sources have been carried out to date. Therefore, the present study's purpose was to evaluate the effect of different dietary protein and lipid levels with a minimal dietary digestible carbohydrates' inclusion level (2\%) on growth performance, feed utilization, proximate composition, digestive and hepatic enzyme activities.

\section{MATERIALS AND METHODS}

Four experimental diets were formulated to contain either 40 or $50 \%$ crude protein combined with either 6 or $12 \%$ fat (Table 1). The ingredients were sieved through a $250 \mu \mathrm{m}$ mesh and then mixed for $30 \mathrm{~min}$ in a standard blender. The dough was extruded and broken down to $3 \mathrm{~mm}$ in particle diameter using a BonnotModel 2EXTWPKR (Ohio, USA) extruder. The dough was dried via ventilation at $60^{\circ} \mathrm{C}$ for $3 \mathrm{~h}$. The feed was sealed in vacuum-packed bags and stored at $-20^{\circ} \mathrm{C}$ until use.

\section{Experimental procedures}

Ocyurus chrysurus juveniles were obtained from Marine Fish Reproduction Laboratory at Unidad Multidisciplinaria de Docencia e Investigación Sisal (Yucatán, México) following the methodology described by Gutiérrez-Sigeros et al. (2018).

The trial was performed in a thermoregulated recirculating water system (Resun CW 1000 chillers, Guandong Risheng Group Co. Ltd, China) operated with 12 rectangular fiberglass tanks with $100 \mathrm{~L}$ water capacity $(73 \times 44 \times 33 \mathrm{~cm})$. Ten fish were placed in each tank $(13.7 \pm 0.45 \mathrm{~g}$ initial weight and $10.5 \pm 0.25 \mathrm{~cm}$ total length), and three replicate groups of fish were used to test each diet. Each diet was randomly assigned. Tanks were supplied with continuous air and seawater flows $\left(5.0 \mathrm{~L} \mathrm{~min}^{-1}\right)$. During the experimental period, the water temperature was $28.1 \pm 0.6^{\circ} \mathrm{C}$; salinity was $36 \pm$ $0.4 \mathrm{~g} \mathrm{~L}^{-1}, \mathrm{pH}$ was $8.2 \pm 0.1$, ammonia concentration was $0.01 \pm 0.0 \mathrm{mg} \mathrm{L}^{-1}$, and dissolved oxygen was $4.1 \pm 0.4$ $\mathrm{mg} \mathrm{L}^{-1}$. Before the experiment, the fish were acclimated to the experimental diet for two weeks. The fish were fed two times a day (10:00 and 18:00 h) at ad libitum. Uneaten feed was collected half an hour after each feeding and then dried (AOAC 1997).

\section{Sample collection}

The growth trial lasted 60 days. The fish were anesthetized with $0.1 \mathrm{mg} \mathrm{mL}^{-1}$ clove oil according to Castillo et al. (2018), then the fish were killer (according to NOM-062-ZOO-1999 recommendations, from México) (SAGARPA 1999). Immediately, the pyloric caeca, intestine, liver, and mesenteric fat were sampled. The liver and mesenteric fats were used to determine the hepatosomatic and fat, mesenteric indices. The pyloric caeca, intestine, and liver were frozen in liquid nitrogen and stored at $-80^{\circ} \mathrm{C}$. The liver was divided into two parts to assess glycogen and metabolic enzymes. Three fish per tank were sampled and pooled to determine the whole-body proximate composition.

\section{Growth performance}

At the end of the experiment, survival (S, \%), weight gain (WG, g), specific growth rate (SGR, \% $\mathrm{d}^{-1}$ ), feed intake (FI, $g$ fish), feed conversion ratio (FCR), the protein efficiency ratio (PER) and hepatosomatic index (HSI) were calculated as follow:

$\mathrm{S}=$ (final number of live fish / initial number of live fish) $\times 100$

$\mathrm{WG}=$ final mean body wet weight $(\mathrm{g})$ - initial mean body wet weight $(\mathrm{g})$

SGR $=($ In [ final mean body wet weight $(\mathrm{g})$ - initial mean body wet weight $(\mathrm{g})]$ / time (day)

$\mathrm{FI}=$ dry food consumer per tank $(\mathrm{g}) /$ number of live fish per tank

PER $=$ WG / dry protein intake $(\mathrm{g})$

HIS $=($ wet weight liver $(\mathrm{g}) /$ wet body weight $(\mathrm{g})) \times$ 100

\section{Proximate analysis}

Crude protein content was determined by flash combustion, then $\mathrm{N}_{2}$ was quantified by thermal conductivity detection using a CHNS elemental analyzer (Costech ECS-4010, Valencia, USA), $\mathrm{N}_{2}$ was converted to protein using a conversion factor of 6.38 (Lynch \& Barbano 1999). Crude lipid levels were determined using the hexane extraction method with a goldfish 
Table 1. Formulation and proximate analysis of the experimental diets (\% dry matter) (40-6: diet with $40 \%$ protein and 6\% lipids; 40-12: $40 \%$ protein and $12 \%$ lipids; 50-6: 50\% protein and 6\% lipids; 50-12: 50\% protein and $12 \%$ lipids). ${ }^{1}$ Proteínas Marinas y Agropecuarias S.A. de C.V. Jalisco, México. ${ }^{2}$ Vimifos, S.A. de C.V. Jalisco, México. ${ }^{3}$ MaltaCleyton S.A. de C.V. Yucatán, México. ${ }^{4}$ DMS Peces Tropicales de Engorda, Nutritional Products México S.A. de C.V. Composition: vitamin $A$, vitamin $D_{3}$, vitamin $E$, vitamin $K_{3}$, vitamin $B_{1}$, vitamin $B_{2}$, vitamin $B_{12}$, folic acid, vitamin $B_{6}$, pantothenic acid, niacin, biotin, choline, vitamin $\mathrm{C}$, iron, manganese, sodium, copper, iodine, zinc, cobalt, selenium, molybdenum, calcium, phosphorus, magnesium, sodium, potassium, carophyll, lysine, threonine, calcium carbonate, methionine, tryptophan, sodium lasalocid, monensin, tylosin, salinomycin, avoparcin, flavomycin arsanilic, amprolium, zinc bacitracin, virginiamycin, calcium propionate, silicic acid, lignosulfonate, lecithin, BHT, BHA, probiotics, glutase keta, lipase, proteases, amylases, cellulases and acemita. ${ }^{5}$ Talc was used as a filler (Dias et al. 1998). It is an inorganic substance, almost insoluble powder in an aqueous solution. The transfer across biological membranes is unlikely. This substance is not toxic to aquatic life (ECHA 2020). ${ }^{6}$ Wheat bran was used as fiber because it contains digestion-resistant starch (Xie et al. 2008) and also non-digestible protein, due it a requirement for a $\mathrm{pH}=12.5$ for digestion (Balandrán-Quintana et al. 2015). Proximate composition: $14 \%$ protein, $4 \%$ lipid, and $86 \%$ carbohydrate. ${ }^{7}$ Energy was calculated using a calorimetric bomb (PARR, Moline, IL, USA).

\begin{tabular}{|c|c|c|c|c|}
\hline Ingredient (\%) & $40-6$ & $40-12$ & $50-6$ & $50-12$ \\
\hline Fish meal $^{1}$ & 46.5 & 46.5 & 57.0 & 57.0 \\
\hline Poultry by-product meal Prime ${ }^{1}$ & 8.0 & 8.0 & 10.0 & 10.0 \\
\hline Soy protein concentrate $^{2}$ & 12.0 & 12.0 & 15.0 & 15.0 \\
\hline Corn starch ${ }^{3}$ & 2.0 & 2.0 & 2.0 & 2.0 \\
\hline Fish oil ${ }^{1}$ & 1.35 & 7.2 & 0.09 & 6.0 \\
\hline Premix ${ }^{4}$ & 2.0 & 2.0 & 2.0 & 2.0 \\
\hline Filler $(\text { talc })^{5}$ & 22.1 & 16.3 & 7.91 & 2.0 \\
\hline Wheat bran ${ }^{6}$ & 5.0 & 5.0 & 5.0 & 5.0 \\
\hline Carboxymethylcellulose ${ }^{3}$ & 1.0 & 1.0 & 1.0 & 1.0 \\
\hline \multicolumn{5}{|l|}{ Proximate analysis $(\%)$} \\
\hline Dry matter & 98.8 & 97.8 & 98.7 & 98.2 \\
\hline Crude protein & 40.1 & 39.8 & 50.1 & 50.9 \\
\hline Lipid & 6.7 & 12.2 & 6.1 & 12.7 \\
\hline Ash & 35.1 & 29.3 & 21.1 & 16.3 \\
\hline Gross energ & 13.6 & 16.4 & 16.6 & 18.6 \\
\hline Protein: energy ratio ( $\mathrm{n}$ & 29.4 & 24.3 & 30.1 & 27.3 \\
\hline Lipids: energy ratio $\left(\mathrm{mg} \mathrm{kJ}^{-1}\right)$ & 4.9 & 7.4 & 3.7 & 6.8 \\
\hline
\end{tabular}

system (Nielsen \& Carpenter 2017). The moisture content was determined after the sample was ovendried and brought to a constant dry weight $\left(60^{\circ} \mathrm{C}\right.$ for $120 \mathrm{~h}$ ). The ash content was determined by combusting the sample in a muffle furnace at $550^{\circ} \mathrm{C}$ for $6 \mathrm{~h}$ (AOAC 1997). The glycogen content was determined using the method reported by Carroll et al. (1956).

\section{Digestive enzyme activity}

The pyloric caeca and intestine were homogenized with an Ultra Turrax IKA T18 homogenizer (North Chase, Wilmington, USA) in $30 \mathrm{mM} \mathrm{L}^{-1}$ Tris- $\mathrm{HCl}+12.5 \mathrm{mM}$ $\mathrm{L}^{-1} \mathrm{CaCl}_{2}$ at $\mathrm{pH} 7.5$ and centrifuged at $1670 \mathrm{~g}$ for $30 \mathrm{~min}$ at $4^{\circ} \mathrm{C}$ (5420R-Eppendorf, Germany).

Total alkaline protease activities were evaluated using Hammarsten-grade casein $(0.05 \%)$ in $100 \mathrm{mM} \mathrm{L}^{-1}$ Tris- $\mathrm{HCl}$ and $10 \mathrm{mM} \mathrm{L}^{-1} \mathrm{CaCl}_{2}$ at $\mathrm{pH} 9$ with the method reported by Kunitz (1947) and modified by Walter
(1984). One unit of enzyme activity was defined as 1 $\mu \mathrm{g}$ of tyrosine released per min at $280 \mathrm{~nm}$.

Trypsin activity was assayed using $\mathrm{N}$-a-benzoylDL-arginine 4-nitroanilide hydrochloride (BAPNA) $3.5 \mathrm{mM} \mathrm{L}^{-1}$ as substrate in $100 \mathrm{mM} \mathrm{L}^{-1}$ tris at $\mathrm{pH} 8$ following the method of Erlanger et al. (1961). Chymotrypsin was evaluated using $\mathrm{N}$-succinyl- ala-alapro-phe p-nitroanilide (SAAPNA) $1 \mathrm{mM} \mathrm{L}^{-1}$ as substrate in $100 \mathrm{mM} \mathrm{L}^{-1}$ tris at $\mathrm{pH} 8$ following the method of DelMar et al. (1979). One enzyme unit was defined as $1 \mu \mathrm{M}$ of p-nitroanilide released per min using a molar extinction coefficient of 8800 at $410 \mathrm{~nm}$.

Bile salt-dependent lipase activity was measured using the method described by Gjellesvik et al. (1992) with 4-nitrophenyl octanoate $\left(1 \mathrm{mM} \mathrm{L}^{-1}\right)$ in $500 \mathrm{mM} \mathrm{L}^{-1}$ tris and $6 \mathrm{mM} \mathrm{L}^{-1}$ sodium taurocholate at $\mathrm{pH}$ 7.4. One lipase activity unit was defined as $1 \mu \mathrm{M} \mathrm{L}^{-1}$ of nitrophenol hydrolyzed per min using a molar extinction coefficient of 16,300 at $415 \mathrm{~nm}$. 


\section{Hepatic key intermediary enzyme activities}

The livers were homogenized (dilution 1:5) in ice-cold buffer ( $50 \mathrm{mM} \mathrm{L}^{-1}$ tris-HCl, $0.5 \mathrm{mM} \mathrm{L}^{-1}$ phenylmethyl sulfonyl fluoride (PMSF), $4 \mathrm{mM} \mathrm{L}^{-1}$ ethylenediaminetetraacetic acid (EDTA), $50 \mathrm{mM} \mathrm{L}^{-1}$ sodium fluoride $(\mathrm{NaF}), 250 \mathrm{mM} \mathrm{L}^{-1}$ sucrose and $500 \mathrm{mM} \mathrm{L}^{-1}$ dithiothreitol (DTT, at pH 7.5) and centrifuged at 1670 $\mathrm{g}$ for $30 \mathrm{~min}$ at $4^{\circ} \mathrm{C}$. The resulting supernatant was separated to assess PK, FBPase, G6PDH and 6PGDH activities. Pyruvate kinase (PK) activity was evaluated in a $0.25 \mathrm{~mL}$ reaction containing $250 \mathrm{mM} \mathrm{L}^{-1}$ glycylglycine, $\mathrm{pH} 7.4,10 \mathrm{mM} \mathrm{L}^{-1} \mathrm{MgCl}_{2}, 100 \mathrm{mM} \mathrm{L}^{-1} \mathrm{KCl}$, $0.15 \mathrm{mM} \mathrm{L}^{-1} \mathrm{NADH}, 2.8 \mathrm{mM} \mathrm{L}^{-1}$ phosphoenolpyruvate, and $21 \mathrm{U} \mathrm{mL}^{-1}$ lactate dehydrogenase. ADP was added at the end of the experiment (Bonamusa et al. 1992). Fructose 1,6 bisphosphatase (FBPase) activity was evaluated in a $0.2 \mathrm{~mL}$ reaction containing $85 \mathrm{mM} \mathrm{L}^{-1}$ imidazole- $\mathrm{HCl}, \mathrm{pH} 7.7,5 \mathrm{mM} \mathrm{L}^{-1} \mathrm{MgCl}_{2}, 0.5 \mathrm{mM} \mathrm{L}^{-1}$ NADP, $12 \mathrm{mM} \mathrm{L}{ }^{-1}$ 2-mercaptoethanol, $0.05 \mathrm{mM} \mathrm{L}^{-1}$ fructose-1,6-diphosphate, $25 \mathrm{U} \mathrm{mL}^{-1}$ phosphoglucose isomerase, and $0.48 \mathrm{U} \mathrm{mL}^{-1}$ glucose-6-phosphate dehydrogenase. Activity of glucose-6-phosphate dehydrogenase $(\mathrm{G} 6 \mathrm{PDH})$ was evaluated in a $0.2 \mathrm{~mL}$ reaction containing $77 \mathrm{mM} \mathrm{L}^{-1}$ imidazole $\mathrm{HCl}, \mathrm{pH} 7.7$, $5 \mathrm{mM} \mathrm{L}^{-1} \mathrm{MgCl}_{2}, 1 \mathrm{mM} \mathrm{L}^{-1} \mathrm{NADP}$, and $10 \mathrm{mM} \mathrm{L}^{-1}$ glucose 6-phosphate. 6-Phosphogluconate dehydrogenase (6PGDH) activity was evaluated in a $0.2 \mathrm{~mL}$ reaction containing $83 \mathrm{mM} \mathrm{L}^{-1}$ imidazole $\mathrm{HCl}, \mathrm{pH} 7.7$, $3 \mathrm{mM} \mathrm{L}^{-1} \mathrm{MgCl}_{2}, 0.5 \mathrm{mM} \mathrm{L}^{-1} \mathrm{NADP}$, and $2 \mathrm{mM} \mathrm{L}^{-1}$ gluconate 6-phosphate (Bonamusa et al. 1992). Alanine aminotransferase (ALT) was measured using a commercial kit (Linear Chemical assay kit ALT/GPT BR opt.).

Enzyme activity was measured using a microplate spectrophotometer (BioTek, Vermont, USA) at $37^{\circ} \mathrm{C}$. Enzyme assays were monitored spectrophotometrically by observing the changes in the absorbance of $\mathrm{NADH} / \mathrm{NAD}$ and NADP/NADPH at $340 \mathrm{~nm}$ (Borrebaek et al. 1993, Tranulis et al. 1996). Digestive and metabolic enzyme activities were reported as $\mathrm{mg}$ of soluble protein (specific activity). According to Bradford (1976), protein concentration was determined using a Sigma protein assay kit with bovine serum albumin as standard.

\section{Statistical analysis}

Data are presented as the mean \pm standard error (SE). The rest of the analyses were performed with a two-way ANOVA test $(P<0.05)$; when a significant interaction resulted in protein and lipid level, a Tukey's test was applied. Before these analyses, the normality and homogeneity of residuals were verified. The analyses were performed with R statistical (R Core Team 2019).

\section{RESULTS}

The growth performance and feed efficiency of Ocyurus chrysurus fed with different protein: lipid ratios for 60 days are shown (Table 2). Survival was not significantly affected by experimental diets. FW, WG, and SGR improved significantly as protein levels increased from 40 to $50 \%$, but no significant differences were observed in lipid levels. FI, PER, and FCR were affected by dietary lipid level $(P<0.05)$ but not dietary protein level $(P>0.05)$. FI and FCR increased significantly as dietary lipid level decreased; whereas, PER showed an opposite trend.

Whole fish composition, liver glycogen, hepatosomatic index are listed in Table 3. Moisture and ash contents of whole-body were significantly affected by protein and lipid levels $(P<0.05)$. As protein level increased and lipid level decreased, moisture content increased significantly; whereas, ash content showed an opposite trend $(P<0.05)$. The whole body's protein content was significantly influenced by dietary protein level but not by dietary lipid level. The protein content of fish fed $40 \%$ dietary protein was substantially higher than that of fish fed $50 \%$ dietary protein $(P<0.05)$. Whole-body lipid and liver glycogen contents were significantly affected by dietary lipid level and increased with increasing dietary lipid level $(P<0.05)$. HSI did not differ among the experimental fish group.

Digestive enzyme activities in the pyloric caeca and intestine of $O$. chrysurus are presented (Tables 4-5), respectively. A significant interaction between dietary protein and lipid levels was observed in alkaline proteases and lipase activities in both digestive organs $(P<0.05)$. In the pyloric caeca, alkaline protease activity was significantly higher for fish fed the 50-12 diets than the rest of the dietary treatments. In the intestine, the alkaline protease activity of fish fed diet 50-12 was significantly higher than that of fish fed the 40-12 diets, but not significantly different from those fed the 40-6 and 50-6 diets. For lipase, fish fed the 406 diet showed significantly higher activity than the rest of dietary treatments in both digestive organs, whereas that of fish fed the 40-12 diet showed the lower lipase activity $(P<0.05)$. Trypsin and chymotrypsin activities were significantly affected by dietary lipid level but not by dietary protein level. Trypsin activity increased significantly as dietary lipid level increased; whereas, chymotrypsin activity showed an opposite trend $(P<$ 0.05).

Hepatic metabolic enzyme activities are shown in Table 6. PK activity was significantly affected by protein and lipid dietary levels and increased with increasing dietary protein and lipid levels. G6PDH, 
Table 2. Growth performance of yellowtail snapper Ocyurus chrysurus fed diets containing different protein: lipid ratio. Values are shown as means \pm standard error mean $(n=3) .{ }^{1} \mathrm{CP}$ denotes crude protein, and CL denotes crude lipid. The number bellowing the letters denotes the level (\%) of protein and lipid formulated for each test diet. ${ }^{2}$ Single capital letters indicate significant difference between main effect means (dietary protein $=\mathrm{A}>\mathrm{B}$; dietary lipid $=\mathrm{Y}>\mathrm{Z}$ ). ${ }^{3}$ Significance terms: NS $=P>0.05 ; * P<0.05 ; * * P<0.01$. IW: initial weight, FW: final weight, WG: weight gain, SGR: specific growth rate, S: survival, FI: food intake, PER: protein efficiency ratio, FCR: feed conversion ratio.

\begin{tabular}{|c|c|c|c|c|c|c|c|c|c|}
\hline $\begin{array}{l}\text { Diet name } \\
\text { (\% protein-\% lipids) }\end{array}$ & $\begin{array}{l}\mathrm{CP}^{1} \\
(\%)\end{array}$ & $\begin{array}{l}\text { CL } \\
(\%)\end{array}$ & $\begin{array}{c}\mathrm{FW} \\
(\mathrm{g})\end{array}$ & $\begin{array}{l}\text { WG } \\
(\mathrm{g})\end{array}$ & $\begin{array}{l}\text { SGR } \\
(\%)\end{array}$ & $\begin{array}{c}\text { FI } \\
\left(\mathrm{g} \mathrm{fish}^{-1}\right)\end{array}$ & PER & FCR & $\begin{array}{c}\mathrm{S} \\
(\%)\end{array}$ \\
\hline $40-6$ & 40 & 6 & $20.1 \pm 0.1$ & $6.1 \pm 0.2$ & $0.66 \pm 0.0$ & $20.8 \pm 0.4$ & $0.74 \pm 0.1$ & $3.41 \pm 0.3$ & $100 \pm 0.0$ \\
\hline $40-12$ & 40 & 12 & $19.5 \pm 0.4$ & $6.3 \pm 0.6$ & $0.77 \pm 0.1$ & $17.1 \pm 1.1$ & $0.92 \pm 0.1$ & $2.76 \pm 0.2$ & $96.6 \pm 3.3$ \\
\hline $50-6$ & 50 & 6 & $20.5 \pm 1.3$ & $6.9 \pm 0.9$ & $0.74 \pm 0.1$ & $22.2 \pm 0.9$ & $0.74 \pm 0.2$ & $3.26 \pm 0.4$ & $96.6 \pm 3.3$ \\
\hline $50-12$ & 50 & 12 & $23.4 \pm 1.2$ & $9.8 \pm 1.1$ & $0.96 \pm 0.1$ & $17.3 \pm 1.4$ & $1.13 \pm 0.0$ & $1.77 \pm 0.1$ & $96.6 \pm 3.3$ \\
\hline \multicolumn{10}{|l|}{ Means of main effects ${ }^{2}$} \\
\hline & 40 & & $20.0 \pm 0.2^{\mathrm{B}}$ & $6.2 \pm 0.3^{\mathrm{B}}$ & $0.68 \pm 0.0^{\mathrm{B}}$ & $18.9 \pm 0.9$ & $0.83 \pm 0.1$ & $3.10 \pm 0.2$ & $98.3 \pm 1.6$ \\
\hline & 50 & & $21.9 \pm 1.0^{\mathrm{A}}$ & $8.3 \pm 0.9^{\mathrm{A}}$ & $0.85 \pm 0.1^{\mathrm{A}}$ & $19.7 \pm 1.3$ & $0.88 \pm 0.2$ & $2.52 \pm 0.4$ & $96.6 \pm 2.1$ \\
\hline & & 6 & $20.3 \pm 0.6$ & $6.5 \pm 0.5$ & $0.69 \pm 0.0$ & $21.5 \pm 0.5^{\mathrm{Y}}$ & $0.68 \pm 0.1^{z}$ & $3.33 \pm 0.2^{\mathrm{Y}}$ & $98.3 \pm 1.6$ \\
\hline & & 12 & $21.7 \pm 0.9$ & $8.0 \pm 0.9$ & $0.82 \pm 0.1$ & $17.2 \pm 0.8^{\mathrm{Z}}$ & $1.03 \pm 0.1^{\mathrm{Y}}$ & $2.67 \pm 0.2^{Z}$ & $96.6 \pm 2.1$ \\
\hline \multicolumn{10}{|l|}{ Two-way ANOVA ${ }^{3}$} \\
\hline Dietary protein & & & * & * & * & NS & NS & NS & NS \\
\hline Dietary lipid & & & NS & NS & NS & ** & ** & ** & NS \\
\hline Interaction & & & NS & NS & NS & NS & NS & NS & NS \\
\hline
\end{tabular}

Table 3. Whole-body composition (wet matter), liver glycogen, and hepatosomatic index of yellowtail snapper Ocyurus chrysurus fed diets containing different protein: lipids ratio. Values are shown as means \pm standard error mean $(\mathrm{n}=3) .{ }^{1} \mathrm{CP}$ denotes crude protein, and CL denotes crude lipid. The number bellowing the letters denotes the level (\%) of protein and lipid formulated for each test diet. ${ }^{2}$ Single capital letters indicate significant difference between main effect means (dietary protein $=\mathrm{A}>\mathrm{B}$; dietary lipid $=\mathrm{Y}>\mathrm{Z}$ ). ${ }^{3}$ Significance terms: NS $=P>0.05 ; *=P<0.05 ; * *=P<0.01 ; * * *=P<0.001$. HIS: hepatosomatic index.

\begin{tabular}{|c|c|c|c|c|c|c|c|c|}
\hline $\begin{array}{l}\text { Diet name } \\
\text { (\% protein-\% lipids) }\end{array}$ & $\begin{array}{l}\mathrm{CP}^{1} \\
(\%)\end{array}$ & $\begin{array}{l}\text { CL } \\
(\%)\end{array}$ & $\begin{array}{l}\text { Moisture } \\
(\%)\end{array}$ & $\begin{array}{l}\text { Protein } \\
(\%)\end{array}$ & $\begin{array}{l}\text { Lipid } \\
(\%)\end{array}$ & $\begin{array}{l}\text { Ash } \\
(\%)\end{array}$ & $\begin{array}{l}\text { Liver glycogen } \\
\left(\mathrm{g} 100 \mathrm{~g} \mathrm{liver}^{-1}\right)\end{array}$ & HSI \\
\hline $40-6$ & 40 & 6 & $69.9 \pm 0.3$ & $18.3 \pm 0.2$ & $3.55 \pm 0.0$ & $5.04 \pm 0.1$ & $0.22 \pm 0.02$ & $1.59 \pm 0.1$ \\
\hline $40-12$ & 40 & 12 & $68.4 \pm 0.3$ & $18.0 \pm 0.1$ & $5.23 \pm 0.2$ & $5.14 \pm 0.1$ & $0.25 \pm 0.02$ & $1.55 \pm 0.1$ \\
\hline $50-6$ & 50 & 6 & $71.2 \pm 0.2$ & $16.7 \pm 0.2$ & $3.75 \pm 0.2$ & $4.89 \pm 0.0$ & $0.22 \pm 0.01$ & $1.34 \pm 0.1$ \\
\hline $50-12$ & 50 & 12 & $69.2 \pm 0.2$ & $16.8 \pm 0.2$ & $5.83 \pm 0.1$ & $4.95 \pm 0.0$ & $0.28 \pm 0.01$ & $1.52 \pm 0.0$ \\
\hline \multicolumn{9}{|l|}{ Means of main effects ${ }^{2}$} \\
\hline & $\begin{array}{l}40 \\
50\end{array}$ & & $\begin{array}{l}69.2 \pm 0.4^{\mathrm{B}} \\
70.2 \pm 0.5^{\mathrm{A}}\end{array}$ & $\begin{array}{l}18.2 \pm 0.1^{\mathrm{A}} \\
16.7 \pm 0.1^{\mathrm{B}}\end{array}$ & $\begin{array}{l}4.39 \pm 0.3 \\
4.79 \pm 0.4\end{array}$ & $\begin{array}{l}5.09 \pm 0.1^{\mathrm{A}} \\
4.92 \pm 0.0^{\mathrm{B}}\end{array}$ & $\begin{array}{l}0.24 \pm 0.01 \\
0.25 \pm 0.02\end{array}$ & $\begin{array}{l}1.57 \pm 0.1 \\
1.43 \pm 0.1\end{array}$ \\
\hline & & 6 & $70.6 \pm 0.3^{Y}$ & $17.5 \pm 0.4$ & $3.65 \pm 0.1^{\mathrm{Z}}$ & $4.97 \pm 0.1^{Z}$ & $0.22 \pm 0.01^{\mathrm{Z}}$ & $1.46 \pm 0.1$ \\
\hline & & 12 & $68.8 \pm 0.2^{\mathrm{Z}}$ & $17.4 \pm 0.3$ & $5.53 \pm 0.1^{\mathrm{Y}}$ & $5.04 \pm 0.2^{\mathrm{Y}}$ & $0.26 \pm 0.01^{\mathrm{Y}}$ & $1.54 \pm 0.1$ \\
\hline \multicolumn{9}{|l|}{ Two-way ANOVA 3} \\
\hline Dietary protein & & & $* *$ & $* * *$ & NS & ** & NS & NS \\
\hline Dietary lipid & & & $* * *$ & NS & $* * *$ & $* * *$ & $*$ & NS \\
\hline Interaction & & & NS & NS & NS & NS & NS & NS \\
\hline
\end{tabular}

6PGDH, and FBPase activities were influenced by dietary lipid level but not by dietary protein level. The activities of the G6PDH, 6PGDH, and FBPase enzymes of the fish fed $12 \%$ dietary lipids were significantly higher than those of the fish fed $6 \%$ lipids. ALT activity was significantly affected by dietary protein level and increased as protein level increased.

\section{DISCUSSION}

This study examined the ability of $O$. chrysurus to utilize dietary lipid as an energy source through four experimental diets with two graded levels of protein (40 and 50\%) and lipid (6 and 12\%), each containing a minimal level of digestible carbohydrates ( $2 \%$ corn starch).

\section{Growth, feed efficiency, and biochemical compo- sition}

Dietary protein content decrement with or without a concomitant increase of non-protein energy content (lipid or carbohydrates) provides an extremely efficient improvement in protein utilization without impacting 
Table 4. Specific activities (in $\mathrm{U} \mathrm{mg}^{-1}$ of protein) of digestive enzymes in the pyloric caeca of yellowtail snapper Ocyurus chrysurus fed diets containing different protein: lipids ratio. Values are shown as means \pm standard error mean $(\mathrm{n}=3) .{ }^{1} \mathrm{CP}$ denotes crude protein, and CL denotes crude lipid. The number bellowing the letters denotes the level (\%) of protein and lipid formulated for each test diet. ${ }^{2}$ Single capital letters indicate significant difference between main effect means (dietary protein $=\mathrm{A}>\mathrm{B}$; dietary lipid $=\mathrm{Y}>\mathrm{Z}$ ). Single lower letters indicate a significant difference between diets at $P<0.05$ by Tukey's test $(\mathrm{a}>\mathrm{b}) .{ }^{3}$ Significance terms: $\mathrm{NS}=P>0.05 ; *=P<0.05 ; * *=P<0.01 ; * * *=P<0.001 .{ }^{4}$ Alkaline protease activities are expressed at $10^{-2} \mathrm{U} \mathrm{mg}$ protein ${ }^{-1}$. Trypsin, chymotrypsin, and lipase activities are expressed at $10^{-4} \mathrm{U} \mathrm{mg}{ }^{1}$.

\begin{tabular}{|c|c|c|c|c|c|c|}
\hline $\begin{array}{l}\text { Diet name } \\
\text { (\% protein-\% lipids) }\end{array}$ & $\begin{array}{l}\mathrm{CP}^{1} \\
(\%)\end{array}$ & $\begin{array}{l}\mathrm{CL} \\
(\%)\end{array}$ & $\begin{array}{l}\text { Alkaline } \\
\text { proteases }^{4}\end{array}$ & Trypsin & Chymotrypsin & Lipase \\
\hline $40-6$ & 40 & 6 & $16.1 \pm 0.6^{\mathrm{b}}$ & $14.9 \pm 3.1$ & $5.77 \pm 0.2$ & $6.90 \pm 0.8^{\mathrm{a}}$ \\
\hline $40-12$ & 40 & 12 & $15.7 \pm 1.1^{\mathrm{b}}$ & $3.28 \pm 0.5$ & $6.36 \pm 0.5$ & $1.68 \pm 0.2^{\mathrm{bc}}$ \\
\hline $50-6$ & 50 & 6 & $17.4 \pm 1.0^{\mathrm{b}}$ & $18.6 \pm 2.4$ & $5.06 \pm 0.2$ & $3.62 \pm 0.2^{\mathrm{b}}$ \\
\hline $50-12$ & 50 & 12 & $24.2 \pm 2.3^{\mathrm{a}}$ & $3.57 \pm 0.2$ & $8.19 \pm 0.9$ & $0.54 \pm 0.0^{c}$ \\
\hline \multicolumn{7}{|l|}{ Means of main effects ${ }^{2}$} \\
\hline & 40 & & $15.9 \pm 0.5^{\mathrm{B} .}$ & $9.08 \pm 2.9$ & $6.07 \pm 0.2$ & $4.29 \pm 1.2^{\mathrm{A}}$ \\
\hline & 50 & & $20.8 \pm 1.9^{\mathrm{A}}$ & $11.1 \pm 3.5$ & $6.63 \pm 0.8$ & $2.08 \pm 0.7^{\mathrm{B}}$ \\
\hline & & 6 & $16.7 \pm 0.6$ & $16.7 \pm 1.9^{\mathrm{Y}}$ & $5.42 \pm 0.2^{Z}$ & $5.26 \pm 0.8^{Y}$ \\
\hline & & 12 & $20.0 \pm 2.2$ & $3.42 \pm 0.3^{Z}$ & $7.28 \pm 0.6^{\mathrm{Y}}$ & $1.11 \pm 0.3^{Z}$ \\
\hline \multicolumn{7}{|l|}{ Two-way ANOVA ${ }^{3}$} \\
\hline Dietary protein & & & ** & NS & NS & *** $*$ \\
\hline Dietary lipid & & & NS & $* * *$ & $* *$ & $* * *$ \\
\hline Interaction & & & $*$ & NS & NS & $*$ \\
\hline
\end{tabular}

Table 5. Specific activities (in $\mathrm{U} \mathrm{mg}^{-1}$ of protein) of digestive enzymes in the intestine of yellowtail snapper Ocyurus chrysurus fed diets containing different protein: lipids ratio. Values are shown as means \pm standard error mean $(\mathrm{n}=3) .{ }^{1} \mathrm{CP}$ denotes crude protein, and CL denotes crude lipid. The number bellowing the letters denotes the level (\%) of protein and lipid formulated for each test diet. ${ }^{2}$ Single capital letters indicate significant difference between main effect means (dietary protein $=\mathrm{A}>\mathrm{B}$; dietary lipid $=\mathrm{Y}>\mathrm{Z}$ ). Single lower letters indicate a significant difference between diets at $P<0.05$ by Tukey's test $(\mathrm{a}>\mathrm{b}) .{ }^{3}$ Significance terms: NS $=P>0.05 ; *=P<0.05 ; * *=P<0.01 ; * * *=P<0.001 .{ }^{4}$ Alkaline protease activities are expressed at $10^{-2} \mathrm{U}$ mg protein ${ }^{-1}$. Trypsin, chymotrypsin, and lipase activities are expressed at $10^{-4} \mathrm{U} \mathrm{mg}^{1}$.

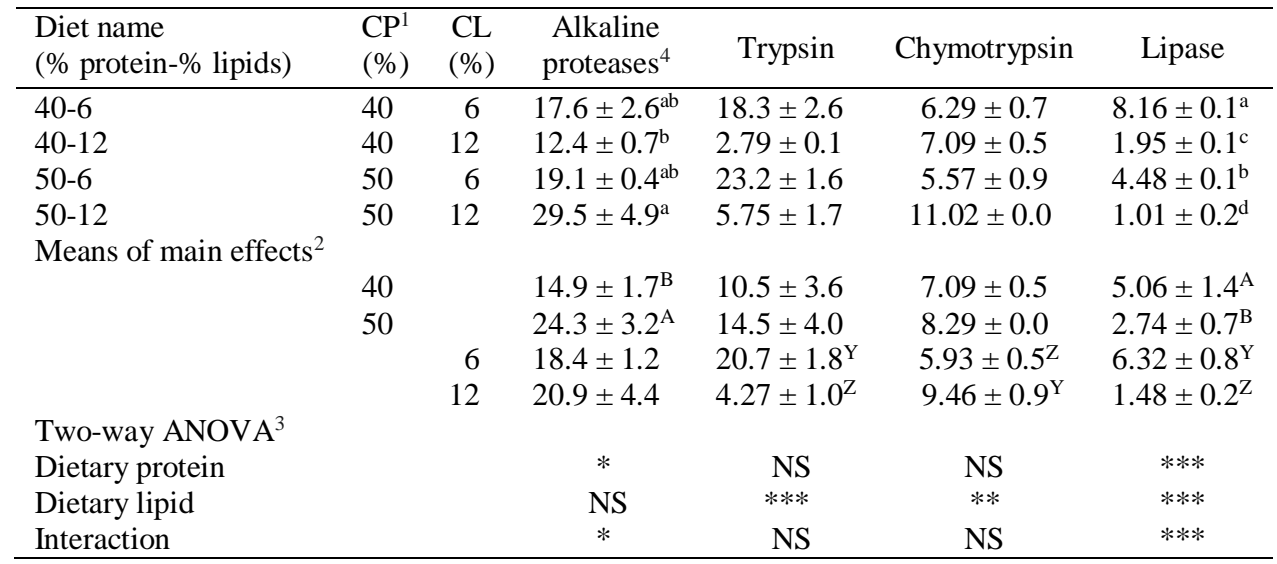

growth in numerous species of fish (NRC 2011). However, in this study, SGR and WG were not affected by lipid levels in the diet. The lack of protein optimization for growth performance by dietary lipid increasing effect, observed in this study, is in line with other species of the same family: mutton snapper (Lutjanus analis) (Watanabe et al. 2001), spotted rose snapper (Lutjanus guttatus) (Abdo de la Parra et al. 2010), red porgy (Pagrus pagrus) (Schuchardt et al. 2008), red mangrove snapper (Lutjanus argentima- culatus) (Catacutan et al. 2001), and red snapper (Lutjanus campechanus) (Miller et al. 2005). According to these data, dietary lipid appears to negatively impact protein utilization efficiency on growth performance in Lutjanidae species.

Dietary energy ranged from 13.6 to $18.6 \mathrm{KJ} \mathrm{g}^{-1}$, and the maximum growth (SGR and WG) was observed in the diets 50-6 and 50-12, which containing 16.6 and $18.6 \mathrm{KJ} \mathrm{g}^{-1}$, respectively. On the other hand, diet 40-12 had a similar energy content: diet 50-6 (16.4 and 16.6 
Table 6. Specific activities (in $\mathrm{U} \mathrm{mg}^{-1}$ of protein) of intermediary metabolic enzymes in liver of yellowtail snapper Ocyurus chrysurus fed diets containing different protein: lipids ratio. Values are shown as means \pm standard error mean $(\mathrm{n}=3) .{ }^{1} \mathrm{CP}$ denotes crude protein, and CL denotes crude lipid. The number bellowing the letters denotes the level (\%) of protein and lipid formulated for each test diet. ${ }^{2}$ Single capital letters indicate significant difference between main effect means (dietary protein $=\mathrm{A}>\mathrm{B}$; dietary lipid $=\mathrm{Y}>\mathrm{Z}$ ). ${ }^{3}$ Significance terms: NS $=P>0.05 ; * P<0.05 ; P<0.001 .{ }^{4}$ ALT activities are expressed at $10^{-2} \mathrm{U} \mathrm{mg}$ protein ${ }^{-1}$. PK: Pyruvate kinase, G6PDH: glucose-6-phosphate dehydrogenase, 6PGDH: 6phosphogluconate dehydrogenase, FBPase: fructose-1, 6-biphosphatase, ALT: alanine aminotransferase.

\begin{tabular}{lcrccccc}
\hline $\begin{array}{l}\text { Diet name } \\
\text { (\% protein- \% lipids) }\end{array}$ & $\begin{array}{l}\text { CP }^{1} \\
(\%)\end{array}$ & $\begin{array}{r}\text { CL } \\
(\%)\end{array}$ & PK & G6PDH & 6PGDH & FBPase & ALT $^{4}$ \\
\hline $40-6$ & 40 & 6 & $4.00 \pm 0.2$ & $22.4 \pm 0.3$ & $12.1 \pm 0.4$ & $6.34 \pm 0.1$ & $5.57 \pm 0.2$ \\
$40-12$ & 40 & 12 & $10.9 \pm 0.5$ & $23.8 \pm 0.4$ & $13.9 \pm 0.5$ & $8.32 \pm 0.5$ & $5.54 \pm 0.3$ \\
$50-6$ & 50 & 6 & $10.4 \pm 0.9$ & $22.1 \pm 0.5$ & $12.6 \pm 0.7$ & $6.41 \pm 0.1$ & $7.55 \pm 0.1$ \\
$50-12$ & 50 & 12 & $14.9 \pm 0.5$ & $24.4 \pm 1.4$ & $16.1 \pm 0.8$ & $8.10 \pm 0.4$ & $8.05 \pm 0.0$ \\
Means of main effects $^{2}$ & & & & & & & \\
& 40 & & $7.46 \pm 1.5^{\mathrm{B}}$ & $23.1 \pm 0.4$ & $13.0 \pm 0.5$ & $7.34 \pm 0.5$ & $5.55 \pm 0.2^{\mathrm{B}}$ \\
& 50 & & $12.7 \pm 1.1^{\mathrm{A}}$ & $23.2 \pm 0.8$ & $14.4 \pm 0.9$ & $7.26 \pm 0.4$ & $7.80 \pm 0.1^{\mathrm{A}}$ \\
& & 6 & $7.21 \pm 1.5^{\mathrm{Z}}$ & $22.2 \pm 0.3^{\mathrm{Z}}$ & $12.3 \pm 0.4^{\mathrm{Z}}$ & $6.38 \pm 0.4^{\mathrm{Z}}$ & $6.54 \pm 0.5$ \\
& 12 & $12.9 \pm 0.9^{\mathrm{Y}}$ & $24.1 \pm 0.6^{\mathrm{Y}}$ & $15.1 \pm 0.6^{\mathrm{Y}}$ & $8.21 \pm 0.5^{\mathrm{Y}}$ & $6.81 \pm 0.6$ \\
Two-way NOVA $^{3}$ & & & $* * *$ & $\mathrm{NS}$ & $\mathrm{NS}$ & $\mathrm{NS}$ & $* * *$ \\
Dietary protein & & & $* * *$ & $*$ & $*$ & $* * *$ & NS \\
Dietary lipid & & & $\mathrm{NS}$ & $\mathrm{NS}$ & $\mathrm{NS}$ & $\mathrm{NS}$ & $\mathrm{NS}$ \\
Interaction & & & & & & & \\
\hline
\end{tabular}

$\mathrm{KJ}^{-1}$, respectively), but fish fed with the diet 40-12 showed a lower growth (SGR and WG) compared to fish fed with the diet 50-6. These data suggest that the slower growth of the $O$. chrysurus registered in the 4012 diet was due to a protein deficiency and not energy. In L. argentimaculatus (Catacutan et al. 2001), $P$. pagrus (Schuchardt et al. 2008), and L. guttatus (Abdo de la Parra et al. 2010), it was also observed that a dietary protein level of $40 \%$ induced poor growth.

In this study, PER and FCR improved with increasing lipids' inclusion in the diet from 6 to $12 \%$. In contrast to the present results, no differences in PER or FCR with dietary lipid level increasing from 6 to $15 \%$ in L. analis (Watanabe et al. 2001), 6 to $12 \%$ in $L$. argentimaculatus (Catacutan et al. 2001), 9 to $15 \%$ in L. guttatus (Abdo de la Parra et al. 2010) and 8 to $14 \%$ in red snapper (Miller et al. 2005). This data suggest that $O$. chrysurus has a relatively higher ability to utilize dietary lipid as an energy source than other snapper species.

In the present study, whole-body lipids increased with dietary lipid content, as previously reported in Malabar grouper (Epinephelus malabaricus) (Tuan \& Williams 2007) and rockfish (Sebastes schlegeli) (Lee et al. 2002). The whole body's protein composition is a relevant indicator to determine the optimal dietary protein requirement in fish. For example, Abbas et al. (2005), in L. argentimaculatus and Mohanta et al. (2008a) in silver barb (Puntius gonionotus), found a maximum whole-body protein content at the minimum dietary protein level for maximum growth for these species. It decreased to higher dietary protein levels. In this study, the whole body's protein content decreased when dietary protein levels increased from 40 to $50 \%$. These data suggest that the protein requirement for $O$. chrysurus could be less than $50 \%$ but greater than $40 \%$.

On the other hand, whole-body moisture content increased with dietary protein levels and decreased with dietary lipid levels. The body moisture content decrease could be explained by the content increase of proteins and lipids in the whole body at the protein and lipid level in the diet. The entire body ash content increased with decreased protein and increased lipid levels in the diet, which agrees with other workers' findings in several other fishes (Alam et al. 2008, Mohanta et al. 2008b).

\section{Digestive enzymes}

The ability of a fish to use a diet successfully in terms of growth and energy probably depends in principle on its set of digestive enzymes and their response to the composition and digestibility of the nutrients in a given diet (Lemieux et al. 1999, Furné et al. 2005, Papoutsoglou \& Lyndon 2006). Thus, an inducible effect on the activity of alkaline protease by the increase in dietary protein content has been documented in fish species, such as Asian sea bass (Lates calcarifer) (Eusebio \& Coloso 2002) and hybrid catfish (Clarias batrachus $\times$ C. gariepinus) (Giri et al. 2003), as well as by increasing dietary lipids in 
European sea bass (Dicentrarchus labrax) (GarcíaMeilán et al. 2016), which could explain the higher alkaline protease activity observed in fish fed the 50-12 diet, which contained the highest levels of protein and lipid in this study

Trypsin and chymotrypsin are considered the main constituents of alkaline protease enzymes and the most important enzymes in the process of protein digestion (Sunde et al. 2004, Rungruangsak-Torrissen et al. 2006). In the present study, trypsin and chymotrypsin activities were not affected by dietary protein content, suggesting that $O$. chrysurus is well suited to protein digestion regardless of its concentration in the diet reported by Lundstedt et al. (2004) for pintado (Pseudoplatystoma corruscans). However, the activity of trypsin and chymotrypsin was affected at the lipid level. For trypsin, the increase of dietary lipid resulted in a decrease in its activity, as previously observed in D. labrax (García-Meilán et al. 2016). Probably due to cholecystokinin (CCK) action, a potent hormone that regulates pancreatic enzyme secretion. Dietary lipid represents an important stimulus for the release of CCK in fish (Murashita et al. 2008, Li et al. 2016). Einarsson et al. (1996) and Tillner et al. (2013) reported an antagonistic effect of CCK on trypsin secretion in Atlantic salmon (Salmo salar) and larvae of Atlantic cod (Gadus morhua), respectively. Therefore, it is probably that the decrease in trypsin activity can be attributed to the effect of CCK due to increased lipids in the diet. Nevertheless, it remains a speculative statement. An improvement in digestion and protein utilization cannot be discarded due to trypsin increase in 6\% lipid in the diet (Krogdahl et al. 1994).

In contrast to trypsin, chymotrypsin activity increased with dietary lipid, indicating that these enzymes were affected differently by dietary lipids in $O$. chrysurus. One possible explanation for these results is that the effect of CCK on chymotrypsin secretion could be the opposite to observed for trypsin (Wicker \& Puigerver 1987). However, further research is needed to prove this fact. The disproportionate behavior of trypsin and chymotrypsin activities concerning alkaline proteases suggests that other constitutive alkaline proteases were affected by dietary lipid and protein contents.

Pancreatic bile salt-dependent lipase has high substrate specificity for triacylglycerols containing long-chain polyunsaturated fatty acids, abundant in the marine food chain (Gjellesvik et al. 1992). Therefore, this enzyme could be considered principal lipase in marine fish (Kurtovic et al. 2009). Gómez-Requeni et al. (2013) found that in silverside (Odontesthes bonariensis), adaptive response of bile salt-dependent lipase to fish oil inclusion in the diet. In this study, bile salt-dependent lipase activity trend to decreased with dietary lipid level increase. However, it is interesting to note that fish fed the lowest energy diet showed a significantly high bile salt-dependent lipase activity and vice versa, suggesting that this enzyme's digestive performance was primarily modulated by energy than the diet lipid content.

\section{Liver enzymes}

Although amino acids are the preferential energy substrate for fish (Jia et al. 2017), it has been shown that an increase of non-protein energy (lipid oH carbohydrates) in the diet can reduce dietary amino acid catabolism in some fish (Fernández et al. 2007, Enes et al. 2008, Wang et al. 2018). In the present study, the amino acid catabolism enzyme ALT was not affected by dietary lipid content changes. In contrast, an increase in dietary protein level resulted in an upregulation of ALT activity. These data suggest that the capacity of $O$. chrysurus to catabolize amino acids depends on protein availability instead of gross energy from the diet, as was found in milkfish (Chanos chanos) (Coloso et al. 1988).

As for the gluconeogenesis pathway, there was no effect of dietary protein content on $O$. chrysurus hepatic FBPase. In contrast, FBPase activity increased with dietary lipid content. Kirchner et al. (2003), in rainbow trout (Oncorhynchus mykiss), hepatic gluconeogenesis (FBPase activity) did depress with dietary lipid content increase due to effective oxidation of them. The FBPase increase activity with dietary lipid level found in this study suggests that lipids were driven by $O$. chrysurus to gluconeogenesis pathway (Rito et al. 2019), as previously observed in largemouth bass (Micropterus salmoides) (Guo et al. 2019) and tropical gar (Atractosteus tropicus) (Guerrero-Zárate et al. 2019). These findings match the higher feed efficiency (FI, PER, and FCR) found for O. chrysurus fed high dietary lipid levels.

Besides the key gluconeogenesis enzyme FBPase, the activity of the key enzyme of glycolysis PK of $O$. chrysurus was also nutritionally stimulated by dietary lipid increased. However, there was no consistent effect increasing PK activity over unaffected FBPase activity when dietary protein level increased. Imbalances between glycolysis and gluconeogenesis pathway have also been reported for numerous fish species (Coloso et al. 1988, Castillo et al. 2018, Guerrero-Zárate et al. 2019, Liu et al. 2020). The up regulation of PK shown in this study could be associated with the glucose budget. Although the ALT activity was higher for fish fed $50 \%$ dietary lipid, it was not reflected on FBPase performance, particularly at 50-6 diet. However, the high dietary protein dependence of $O$. chrysurus shown 
in this study (growth) suggests an active ATP production by oxidation of amino acids at $50 \%$ dietary protein level (Walton \& Cowey 1982).

G6PDH and 6PGDH are key enzymes of the pentose phosphate pathway involved in NADPH production necessary for fatty acid synthesis (Tocher 2003). In this study, G6PDH and 6PGDH activity did not change by dietary protein content, whereas an increase of dietary lipid content resulted in an activity enhancement for both enzymes. These data indicate that lipogenesis was stimulated by a high dietary lipid content, which also was reflected in high whole-body lipid. Lipogenesis as well glycogen synthesis are adaptive mechanisms of homeostasis glucose (Enes et al. 2009). Therefore, the high stimulation of lipogenesis and hepatic glycogen content at $12 \%$ dietary lipids indicate that endogenous glucose synthesis rate was higher than its oxidation rate, as was described by Guo et al. (2019) for M. salmoides.

The present study results indicate an increase in dietary lipid level from 6 to $12 \%$ enhanced liver gluconeogenesis, glycolytic and lipogenic pathways but did not depress amino acid catabolism in juvenile O. chrysurus. The high dietary lipid level (12\%) improved feed efficiency but did not reduce protein demand in the diet in juvenile $O$. chrysurus.

\section{ACKNOWLEDGEMENTS}

This study was supported by the Posgrado en Ciencias del Mar y Limnología, Universidad Nacional Autónoma de México and CONACYT (Consejo Nacional de Ciencia y Tecnología, México Project \#164673). The authors thank Juan Carlos Maldonado, Jaime Suárez Bautista, Gabriela Palomino and Patricia Balam, Unidad Académica Sisal-UNAM, for technical support.

\section{REFERENCES}

Abbas, G., Jamil, K., Akhtar, R. \& Hong, L. 2005. Effects of dietary protein level on growth and utilization of protein and energy by juvenile mangrove red snapper (Lutjanus argentimaculatus). Journal of Ocean University of China, 4: 49-55. doi: 10.1007/s11802-0050023-5

Abdo de la Parra, M., Rodríguez-Ibarra, L.E., Hernández, C., Hernández, K., González-Rodríguez, B., MartínezRodríguez, I. \& García-Ortega, A. 2010. Efecto de diferentes niveles de proteína y lípidos totales en la dieta sobre el crecimiento y supervivencia de juveniles de pargo lunarejo Lutjanus guttatus. Revista de
Biología Marina y Oceanografía, 45: 433-439. doi: 10.4067/S0718-19572010000300008

Alam, M.S., Watanabe, W.O. \& Carrol, P.M. 2008. Dietary protein requirements of juvenile black sea bass, Centropristis striata. Journal of the World Aquaculture Society, 39: 656-663. doi: 10.1111/j.17 49-7345.2008.00204.x

Association of the Official Analytical Chemists (AOAC). 1997. Official methods of analysis of the Association of the Official Analytical Chemists. AOAC, Washington, DC.

Balandrán-Quintana, R.R., Mercado-Ruiz, J.N. \& Mendoza-Wilson, A.M. 2015. Wheat bran proteins: a review of their uses and potential. Food Reviews International, 31: 279-293. doi: 10.1080/87559129. 2015.1015137

Bonamusa, L., Garcia de Frutis, P., Fernandez, F. \& Baanante, I. 1992. Nutritional effects on key glycolytic-gluconeogenic enzyme activities and metabolite levels in the liver of the teleost fish Sparus aurata. Molecular Marine Biology and Biotechnology, 1: 113-124.

Borrebaek, B., Waagbø, R., Christophersen, B., Tranulis, M.A. \& Hemre, G.I. 1993. Adaptable hexokinase with low affinity for glucose in the liver of Atlantic salmon (Salmo salar). Comparative Biochemistry and Physiology - Part B: Biochemistry \& Molecular Biology, 106: 833-836. doi: 10.1016/0305-0491(93)90038-7

Bradford, M.M. 1976. A rapid and sensitive method for the quantitation of microgram quantities of protein utilizing the principle of protein-dye binding. Analytical Biochemistry, 72: 248-254. doi: 10.1016/0003-2697(76) 90527-3

Brulé, T., Nóh-Quiñones, V.E., Sánchez-Crespo, M., Colás-Marrufo, T. \& Pérez-Díaz, E. 2008. Composición de las capturas comerciales del complejo meropargo en el sureste del Golfo de México e implicaciones para el manejo de su pesquería comercial. Gulf and Caribbean Fisheries Institute, 61: 198-209.

Carroll, N.V., Longley, R.W. \& Roe, J.H. 1956. The determination of glycogen in liver and muscle by use of anthrone reagent. Journal of Biological Chemistry, 220: 583-593. doi: 10.1016/S0021-9258(18)65284-6

Castillo, A., Alvarez, A., Cuzon, G., Suárez, J. \& Gaxiola, G. 2018. Glycemic response after glucose oral administration of wild juvenile red grouper Epinephelus morio fed two different diets. Fish Physiology and Biochemistry, 44: 1-8. doi: 10.1007/s10695-017-0426-4

Catacutan, M.R., Pagador, G.E. \& Teshima, S. 2001. Effect of dietary protein and lipid levels and protein to energy ratios on growth, survival and body composition of the mangrove red snapper, Lutjanus argentimaculatus (Forsskal 1775). Aquaculture Re- 
search, 32: 811-818. doi: 10.1046/j.1365-2109.2001. 00618.x

Cladis, D.P., Kleiner, A.C., Freiser, H.H. \& Santerre, C.R. 2014. Fatty acid profiles of commercially available finfish fillets in the United States. Lipids, 49: 10051018. doi: 10.1007/s11745-014-3932-5

Coloso, R.M., Benitez, L.V. \& Tiro, L.B. 1988. The effect of dietary protein-energy levels on growth and metabolism of milkfish (Chanos chanos Forsskal). Comparative Biochemistry and Physiology - Part A: Molecular \& Integrative Physiology, 89: 11-17. doi: 10.1016/0300-9629(88)91132-2

DelMar, E.G., Largman, C., Brodrick, J.W. \& Geokas, M.C. 1979. A sensitive new substrate for chymotrypsin. Analytical Biochemistry, 99: 316-320. doi: 10.1016/S0003-2697(79)80013-5

Dias, J., Huelvan, C., Dinis, M.T. \& Métailler, R. 1998. Influence of dietary bulk agents (silica, cellulose and a natural zeolite) on protein digestibility, growth, feed intake and feed transit time in European seabass (Dicentrarchus labrax) juveniles. Aquatic Living Resources, 11: 219-226. doi: 10.1016/S0990-7440(98) 89004-9

Einarsson, S., Davies, P.S. \& Talbot, C. 1996. The effect of feeding on the secretion of pepsin, trypsin and chymotrypsin in the Atlantic salmon, Salmo salar L. Fish Physiology and Biochemistry, 15: 439-446. doi: 10.1007/BF01875587

Enes, P., Panserat, S., Kaushik, S. \& Oliva-Teles, A. 2008. Growth performance and metabolic utilization of diets with native and waxy maize starch by gilthead sea bream (Sparus aurata) juveniles. Aquaculture, 274: 101-108. doi: 10.1016/j.aquaculture.2007.11.009

Enes, P., Panserat, S., Kaushik, S. \& Oliva-Teles, A. 2009. Nutritional regulation of hepatic glucose metabolism in fish. Fish Physiology and Biochemistry, 35: 519539. doi: 10.1007/s10695-008-9259-5

Enríquez, M., Gaxiola, G. \& Pacheco, E. 2017. Efecto de cinco niveles de proteína en el crecimiento de juveniles de pargo canané (Ocyurus chrysurus). In: Cruz, L.E., Marie, D.R., Tapia, S.M., Nieto, L.M.G., Villareal, C.D.A., Gamboa, D.J., et al. (Eds.). XIV International Symposium Aquaculture Nutrition, Ensenada, pp 6667.

Erlanger, B.F., Kokowsky, N. \& Cohen, W. 1961. The preparation and properties of two new chromogenic substrates of trypsin. Archives of Biochemistry and Biophysics, 95: 271-278. doi: 10.1016/00039861(61)90145-X

European Chemicals Agency (ECHA). 2020. Talc (Mg3H2(SiO3)4). [https://www.echa.europa.eu/web/ guest/registration-dossier/-/registered-dossier/18727/6/ 2/3]. Reviewed: November 15, 2020.

Eusebio, P.S. \& Coloso, R.M. 2002. Proteolytic enzyme activity of juvenile Asian sea bass, Lates calcarifer (Bloch), is increased with protein intake. Aquaculture Research, 33: 569-574. doi: 10.1046/j.1365-2109. 2002.00682.x

Fernández, F., Miquel, A.G., Córdoba, M., Varas, M., Metón, I., Caseras, A. \& Baanante, I.V. 2007. Effects of diets with distinct protein-to-carbohydrate ratios on nutrient digestibility, growth performance, body composition and liver intermediary enzyme activities in gilthead sea bream (Sparus aurata, L.) fingerlings. Journal of Experimental Marine Biology and Ecology, 343: 1-10. doi: 10.1016/j.jembe.2006.10.057

Furné, M., Hidalgo, M.C., López, A., García-Gallego, M., Morales, A.E., Domezain, A. \& Sanz, A. 2005. Digestive enzyme activities in Adriatic sturgeon Acipenser naccarii and rainbow trout Oncorhynchus mykiss. A comparative study. Aquaculture, 250: 391398. doi: 10.1016/j.aquaculture.2005.05.017

García-Meilán, I., Ordóñez-Grande, B., Machahua, C., Buenestado, S., Fontanillas, R. \& Gallardo, M.A. 2016. Effects of dietary protein-to-lipid ratio on digestive and absorptive processes in sea bass fingerlings. Aquaculture, 463: 163-173. doi: 10.1016/ j.aquaculture.2016.05.039

Giri, S.S., Sahoo, S.K., Sahu, A.K. \& Meher, P.K. 2003. Effect of dietary protein level on growth, survival, feed utilization and body composition of hybrid Clarias catfish (Clarias batrachus $\times$ Clarias gariepinus). Animal Feed Science and Technology, 104: 169-178. doi: 10.1016/S0377-8401(02)00295-X

Gjellesvik, D.R., Lombardo, D. \& Walther, B.T. 1992. Pancreatic bile salt-dependent lipase from cod (Gadus morhua): purification and properties. Biochimica et Biophysica Acta, 1124: 123-134. doi: 10.1016/00052760(92)90088-d

Gómez-Requeni, P., Bedolla-Cázares, F., Montecchia, C., Zorrilla, J., Villian, M., Toledo-Cuevas, E.M. \& Canosa, F. 2013. Effects of increasing the dietary lipid levels on the growth performance, body composition and digestive enzyme activities of the teleost pejerrey (Odontesthes bonariensis). Aquaculture, 416-417: 1522. doi: 10.1016/j.aquaculture.2013.08.027

Guerrero-Zárate, R., Álvarez-González, C.A., JesusContreras, R., Peña-Marín, E.S., Martínez-García, R., Galaviz, M.A., et al. 2019. Evaluation of carbohydrate/lipid ratios on growth and metabolic response in tropical gar (Atractosteus tropicus) juvenile. Aquaculture Research, 50: 1812-1823. doi: 10.1111/are. 14060

Guo, J., Zhou, Y., Zhao, H., Chen, W.Y., Chen, Y.J. \& Lin, S.M. 2019. Effect of dietary lipid level on growth, lipid metabolism and oxidative status of largemouth 
bass, Micropterus salmoides. Aquaculture, 506: 394400. doi: 10.1016/j.aquaculture.2019.04.007

Gutiérrez-Sigeros, I., Ibarra-Castro, L., AlvarezLajonchère, L. \& Sanchez-Zamora, A. 2018. Natural spawning and scaling-up of yellowtail snapper (Ocyurus chrysurus): larval rearing for the mass production of juveniles. Aquaculture, 491: 252-257. doi: 10.1016/j.aquaculture.2018.03.048

Jia, S., Li, X., Zheng, S. \& Wu, G. 2017. Amino acids are major energy substrates for tissues of hybrid striped bass and zebrafish. Amino Acids, 49: 2053-2063. doi: 10.1007/s00726-017-2481-7

Kim, K.W., Wang, X., Choi, S.M., Park, G.J. \& Bai, S.C. 2004. Evaluation of optimum dietary protein-toenergy ratio in juvenile olive flounder Paralichthys olivaceus (Temminck et Schlegel). Aquaculture Research, 35: 250-255. doi: 10.1111/j.1365-2109. 2004.01003.x

Kirchner, S., Kaushik, S. \& Panserat, S. 2003. Low protein intake is associated with reduced hepatic gluconeogenic enzyme expression in rainbow trout (Oncorhynchus mykiss). Journal of Nutrition, 133: 2561-2564. doi: 10.1093/jn/133.8.2561

Krogdahl, A., Lea, T.B. \& Olli, J.J. 1994. Soybean proteinase inhibitors affect intestinal trypsin activities and amino acid digestibilities in rainbow trout (Oncorhynchus mykiss). Comparative Biochemistry and Physiology - Part A: Molecular \& Integrative Physiology, 107: 215-219. doi: 10.1016/0300-9629 (94) $90296-8$

Kunitz, M. 1947. Crystalline soybean trypsin inhibitor: II. General properties. Journal of General Physiology, 30: 291-310. doi: 10.1085/jgp.30.4.291

Kurtovic, I., Marshall, S.N., Zhao, X. \& Simpson, B.K. 2009. Lipases from mammals and fishes. Reviews in Fisheries Science, 17: 18-40. doi: 10.1080/10641260 802031322

Lee, S.M., Jeon, I.G. \& Lee, J.Y. 2002. Effects of digestible protein and lipid levels in practical diets on growth, protein utilization and body composition of juvenile rockfish (Sebastes schlegeli). Aquaculture, 211: 227-239. doi: 10.1016/S0044-8486(01)00880-8

Lemieux, H., Blier, P. \& Dutil, J.D. 1999. Do digestive enzymes set a physiological limit on growth rate and food conversion efficiency in the Atlantic cod (Gadus morhua)? Fish Physiology and Biochemistry, 20: 293303. doi: 10.1023/A:1007791019523

Li, A., Yuan, X., Liang, X.F., Liu, L., Li, J., Li, B., et al. 2016. Adaptations of lipid metabolism and food intake in response to low and high-fat diets in juvenile grass carp (Ctenopharyngodon idellus). Aquaculture 457: 43-49. doi: 10.1016/j.aquaculture.2016.01.014

Liu, H., Yang, J.J., Dong, X.H., Tan, B.P., Zhang, S., Chi, S.Y., et al. 2020. Effects of different dietary carbohydrate-to-lipid ratios on growth, plasma biochemical indexes, digestive, and immune enzymes activities of sub-adult orange-spotted grouper Epinephelus coioides. Fish Physiology and Biochemistry, 46: 1409-1420. doi: 10.1007/s10695-02000799-4

Lundstedt, L.M., Melodo, J.F.B. \& Moraes, G. 2004. Digestive enzymes and metabolic profile of Pseudoplatystoma corruscans (Teleostei: Siluriformes) in response to diet composition. Comparative Biochemistry and Physiology - Part B: Biochemistry \& Molecular Biology, 137: 331-339. doi: 10.1016/ j.cbpc.2003.12.003

Lynch, J.M. \& Barbano, D.M. 1999. Kjeldahl nitrogen analysis as a reference method for protein determination in dairy products. Journal of AOAC International, 82: 1389-1392. doi: 10.1093/jaoac/ 82.6.1389

McClellan, D.B. \& Cummings, N.J. 1998. Fishery and biology of the yellowtail snapper, Ocyurus chrysurus, from the southeastern United States, 1962 through 1996. Gulf and Caribbean Fisheries Institute, 50: 827850.

Miller, C.L., Davis, D.A. \& Phelps, R.P. 2005. The effects of dietary protein and lipid on growth and body composition of juvenile and sub-adult red snapper, Lutjanus campechanus (Poey, 1860). Aquaculture Research, 36: 52-60. doi: 10.1111/j.1365-2109.2004. 01183.x

Mohanta, K.N., Mohanty, S.N., Jena, J.K. \& Sahu, N.P. 2008a. Protein requirement of silver barb, Puntius gonionotus fingerlings. Aquaculture Nutrition, 14: 143-152. doi: 10.1111/j.1365-2095.2007.00514.x

Mohanta, K.N., Mohanty, S.N., Jena, J.K. \& Sahu, N.P. 2008b. Optimall dietary lipid level of silver barb, Puntius gonionotus fingerlings in relation to growth, nutrient retention and digestibility, muscle nucleic acid content and digestive enzyme activity. Aquaculture Nutrition, 14: 350-359. doi: 10.1111/j.1365-2095. 2007.00542.x

Murashita, K., Fukada, H., Rønnestad, I., Kurokawa, T. \& Masumoto, T. 2008. Nutrient control of release of pancreatic enzymes in yellowtail (Seriola quinqueradiata): involvement of CCK and PY in the regulatory loop. Comparative Biochemistry and Physiology - Part A: Molecular \& Integrative Physiology, 150: 438-443. doi: 10.1016/j.cbpa.2008. 05.003

Nielsen, S.S. \& Carpenter, C.E. 2017. Food content determination. In: Suzanne-Nielsen, S. (Ed.). Food analysis (Food science and text series). Springer, Berlin, pp. 117-119. 
National Research Council (NRC). 2011. Nutrient requirements of fish and shrimp. The National Academies Press, Washington, DC.

Oliva-Teles, A.O., Couto, A., Enes, P. \& Peres, H. 2020. Dietary protein requirements of fish - a meta-analysis. Reviews in Aquaculture, 12: 1445-1477. doi: 10.1111/ raq. 12391

Papoutsoglou, E.S. \& Lyndon, A.R. 2006. Digestive enzymes of Anarhichas minor and the effect of diet composition on their performance. Journal of Fish Biology, 69: 446-460. doi: 10.1111/j.1095-8649.2006. 01108.x

Peres, H. \& Oliva-Teles, A. 1999. Effect of dietary lipid level on growth performance and feed utilization by European sea bass juveniles (Dicentrarchus labrax). Aquaculture, 179: 325-334. doi: 10.1016/S0044-8486 (99)00168-4

R Core Team. 2019. R: a language and environment for statistical computing. R Foundation for Statistical Computing. [http://www.R-project.org]. Reviewed: November 15, 2020.

Rito, J., Viegas, I., Pardal, M., Metón, I., Baanante, I.V. \& Jones, J.G. 2019. Utilization of glycerol for endogenous glucose and glycogen synthesis in seabass (Dicentrarchus labrax): a potential mechanism for sparing amino acid catabolism in carnivorous fish. Aquaculture, 498: 488-495. doi: 10.1016/j.aquaculture.2018.08.066

Rungruangsak-Torrissen, K., Moss, R., Andresen, L.H., Berg, A. \& Waagbø, R. 2006. Different expressions of trypsin and chymotrypsin in relation to growth in Atlantic salmon (Salmo salar L.). Fish Physiology and Biochemistry, 32: 7-23. doi: 10.1007/s10695-0050630-5

Secretaría de Agricultura, Ganadería, Desarrollo Rural, Pesca y Alimentación (SAGARPA). 1999. Norma oficial mexicana, especificaciones técnicas para la producción, cuidado y uso de los animales de laboratorio. Diario Oficial: 1-58. [http://www.fmvz. unam.mx/fmvz/principal/archivos/062ZOO.PDF]. Reviewed: November 15, 2020.

Schuchardt, D., Vergara, J.M., Fernández-Palacios, H., Kalinowski, C.T., Hernández-Cruz, C.M., Izquierdo, M.S. \& Robaina, L. 2008. Effects of different dietary protein and lipid levels on growth, feed utilization and body composition of red porgy (Pagrus pagrus) fingerlings. Aquaculture Nutrition, 14: 1-9. doi: 10.1111/j.1365-2095.2007.00484.x

Shimeno, S., Hosokawa, H. \& Takeda, M. 1996. Metabolic response of juvenile yellowtail to dietary carbohydrate to lipid ratios. Fisheries Science, 62: 945-949. doi: 10.2331/fishsci.62.945

Shimeno, S., Hosokawa, H., Takeda, M., Takayama, S., Fukui, A. \& Sasaki, H. 1981. Adaptation of hepatic enzymes to dietary lipid in young yellowtail. Bulletin of the Japanese Society of Scientific Fisheries, 47: 6369.

Sunde, J., Eiane, S.A., Rustad, A., Jensen, H.B., Opstvedt, J., Nygård, E., et al. 2004. Effect of fish feed processing conditions on digestive protease activities, free amino acid pools, feed conversion efficiency and growth in Atlantic salmon (Salmo salar L.). Aquaculture Nutrition, 10: 261-277. doi: 10.1111/j.13652095.2004.00300.x

Tillner, R., Rønnestad, I., Harboe, T. \& Ueberschär, B. 2013. Evidence for a regulatory loop between cholecystokinin (CCK) and tryptic enzyme activity in Atlantic cod larvae (Gadus morhua). Comparative Biochemistry and Physiology - Part A: Molecular \& Integrative Physiology, 166: 490-495. doi: 10.1016/ j.cbpa.2013.08.001

Tocher, D.R. 2003. Metabolism and functions of lipids and fatty acids in teleost fish. Reviews in Fisheries Science, 11: 107-184. doi: 10.1080/713610925

Tranulis, M.A., Dregni, O., Christophersen, B., Krogdahl, A. \& Borrebaek, B. 1996. A glucokinase-like enzyme in the liver of Atlantic salmon (Salmo salar). Comparative Biochemistry and Physiology - Part B: Biochemistry \& Molecular Biology, 114: 35-39. doi: 10.1016/0305-0491(95)02119-1

Tuan, L.A. \& Williams, K.C. 2007. Optimum dietary protein and lipid specifications for juvenile malabar grouper (Epinephelus malabaricus). Aquaculture, 267: 129-138. doi: 10.1016/j.aquaculture.2007.03.007

Turano, M.J., Davis, D.A. \& Arnold, C.R. 2000. Observations and techniques for maturation, spawning, and larval rearing of the yellowtail snapper Ocyurus chrysurus. Journal of the World Aquaculture Society, 31: 59-68. doi: 10.1111/j.1749-7345.2000.tb0 0698.x

Walter, H.E. 1984. Proteinases: methods with hemoglobin, casein, and azocoll as substrates. In: Bergmeyer, H.U. (Ed.). Methods of enzymatic analysis. Verlag Chemie, Weinheim, pp. 270-277.

Walton, M.J. \& Cowey, C.B. 1982. Aspect of intermediary metabolism in salmonid fish. Comparative Biochemical and Physiology - Part B: Biochemical \& Molecular Biology, 73 : 59-79. doi: 10.1016/00166480(75)90235-X

Wang, C., Hu, G., Sun, P., Gu, W., Wang, B., Xu, Q. \& Liu, H. 2018. Effects of dietary protein at two lipid levels on growth, gonadal development, body composition and liver metabolic enzymes of brown trout (Salmo trutta fario) broodstock. Aquaculture Nutrition, 24: 1587-1598. doi: 10.1111/anu.12795

Watanabe, W.O., Ellis, S.C. \& Chaves, J. 2001. Effects of dietary lipid and energy to protein ratio on growth and feed utilization of juvenile mutton snapper Lutjanus 
analis fed isonitrogenous diets at two temperatures. Journal of the World Aquaculture Society, 32: 30-40. doi: 10.1111/j.1749-7345.2001.tb00919.x

Watanabe, W.O., Ellis, E.P., Ellis, S.C., Chaves, J., Manfredi, C. \& Hagood, R.W. 1998. Artificial propagation of mutton snapper Lutjanus analis, a new candidate marine fish species for aquaculture. Journal of the World Aquaculture Society, 29: 179-187. doi: 10.1111/j.1749-7345.1998.tb00977.x

Wicker, C. \& Puigerver, A. 1987. Effects of inverse changes in dietary lipid and carbohydrate on the synthesis of some pancreatic secretory proteins. European Journal of Biochemistry, 162: 25-30. doi: 10.1111/j.1432-1033.1987.tb10536.x

Received: November 3, 2020; Accepted: February 7, 2021
Xie, X., Cui, S.W., Li, W. \& Tsao, R. 2008. Isolation and characterization of wheat bran starch. Food Research International, 41: 882-887. doi: 10.1016/j.foodres. 2008.07.016

Zhou, P., Wang, M., Xie, F., Deng, D.F. \& Zhou, Q. 2016. Effects of dietary carbohydrate to lipid ratios on growth performance, digestive enzyme, and hepatic carbohydrate metabolic enzyme activities of large yellow croaker (Larmichthys crocea). Aquaculture, 452: 45-51. doi: 10.1016/j.aquaculture.2015.10.010 